\title{
Perbandingan Metode Segmentasi SOM dan Fuzzy $C$ - Means pada Content-Based Image Retrieval Berbasis Warna
}

\author{
I Gusti Ngurah Winanda Wijaksana ${ }^{1}$, Ida Ayu Dwi Giriantari ${ }^{2}$, Made Sudarma ${ }^{3}$
}

\begin{abstract}
The difficulty of determining the right keywords to get the right image is the disadvantages of image search methods based on metadata keywords. Current technology developments lead to content-based image retrieval (CBIR). One feature of image content used for image retrieval is the color feature. To improve CBIR performance, this study investigated the comparison between SOM and Fuzzy C-Means segmentation methods. This segmentation method separates the foreground and background of the query image to get better CBIR performance. This study used Wang Dataset image database. Testing is done with test images that have undergone scale, rotation and blurring. The results of the test show that the segmentation method improves the recall value or the true image that has been found, but significantly reduces the precision value or the true image ratios of the overall images found compared without using segmentation method.
\end{abstract}

Intisari- Sulitnya menentukan kata kunci yang tepat untuk mendapatkan citra yang diinginkan merupakan kelemahan pencarian citra berdasarkan kata kunci metadata. Perkembangan teknologi saat ini mengarah pada pencarian citra berdasarkan konten atau Content-based Image Retrieval (CBIR). Salah satu ciri konten citra yang digunakan untuk temu kembali citra adalah ciri warna. Untuk semakin meningkatkan kinerja CBIR, pada penelitian ini diteliti mengenai perbandingan metode segmentasi SOM dan Fuzzy C-Means. Metode segmentasi ini memisahkan foreground dan background dari citra query untuk mendapatkan kinerja CBIR yang lebih baik. Adapun database citra yang digunakan adalah Wang Dataset. Pengujian dilakukan dengan citra uji yang telah mengalami perubahan skala, rotasi dan kekaburan. Hasil dari pengujian menunjukkan penggunaan metode segmentasi meningkatkan nilai recall atau citra benar yang berhasil ditemukan, namun secara signifikan mengurangi nilai precision atau rasio citra benar dari keseluruhan citra yang ditemukan dibandingkan tanpa mengunakan metode segmentasi.

Kata Kunci-CBIR, Color Moment, SOM, FCM.

\section{Pendahuluan}

Media citra yang semakin lama semakin banyak jumlahnya

\footnotetext{
${ }^{1}$ Mahasiswa, Magister Teknik Elektro Universitas Udayana, Gedung Pascasarjana Jl. PB Sudirman Denpasar-Bali 80232 (tlp/fax: 0361-239599; e-mail: ignwinanda@gmail.com)

2, 3 Dosen, Magister Teknik Elektro Universitas Udayana, Gedung Pascasarjana Jl. PB Sudirman Denpasar-Bali 80232 (tlp/fax: 0361-239599; e-mail: dayu.giriantari@unud.ac.id, sudarma@unud.ac.id)
}

di dunia maya menyebabkan pencarian citra menggunakan kata kunci tekstual baik dilakukan dengan pemberian identitas citra berdasarkan nama berkas, tanggal pengambilan, pemilik citra, atau pendeskripsian citra secara manual semakin sulit untuk dilakukan [1]. Oleh karena itu, sistem temu kembali citra dengan menggunakan isi (content based) mulai dikembangkan untuk mengatasi permasalahan tersebut dimana Content Based Image Retrieval (CBIR) merupakan sebuah ide untuk mencari isi visual citra secara langsung. Adapun fitur utama dalam proses pencarian citra berbasis konten yaitu dengan menggunakan fitur warna, tekstur dan bentuk. Proses utama pada CBIR ada tiga yaitu: (1) Preprocessing, (2) Ekstraksi Ciri dan (3) Matching Features. Untuk meningkatkan kinerja CBIR beberapa penelitian mulai mengembangkan teknik-teknik pada proses prepocessing atau pra pemrosesan dan matching feature atau pencocokan ciri.

Penelitian [2] menggunakan metode pembagian region citra pada proses preprocessing. Proses pembagian citra menjadi tiga region ini mempersempit proses pencocokan, sehingga hasil pencocokan menjadi lebih akurat dibandingkan menggunakan keseluruhan citra tanpa dibagi terlebih dahulu kedalam region yang lebih kecil.

Penelitian [3] bertujuan untuk mengkonversi citra dengan format RGB menjadi enam format berbeda yaitu: Red High, Red Low, Green High, Green Low, Blue High dan Blue Low serta metode Grid Partitioning dengan mempartisi citra menjadi tiga bagian yaitu bagian atas, tengah dan bawah pada CBIR Color Moment menggunakan database citra dari Wang Dataset [4] sehingga ditarik kesimpulan dari hasil penelitian ini yaitu perlu diawali dengan segmentasi citra untuk mendapatkan hasil yang lebih maksimal dengan menyarankan metode segmentasi yang memisahkan antara foreground dan background. Salah satu metode segmentasi citra yang dapat memisahkan antara foreground dan background citra yaitu menggunakan metode SOM [5] dan Metode Fuzzy C-Means [6], [7]. Penelitian [8] menerapkan metode SOM untuk melakukan proses segmentasi citra menghasilkan segmentasi citra yang sangat baik ditandai dengan berkurangnya region noise pada citra.

Berdasarkan ide dari penelitian-penelitian tersebut, dimana proses awal atau preprocessing dioptimalkan dengan tambahan metode, maka penelitian ini mengambil topik CBIR dengan menggukanan ektraksi ciri warna dengan metode Color Moment serta segmentasi citra dengan metode SOM dan Fuzzy C-Means.

\section{Perancangan Sistem}

Berdasarkan gambaran umum sistem dapat dijabarkan perancangan sistem menjadi sistem pelatihan citra dan sistem pengujian citra: 


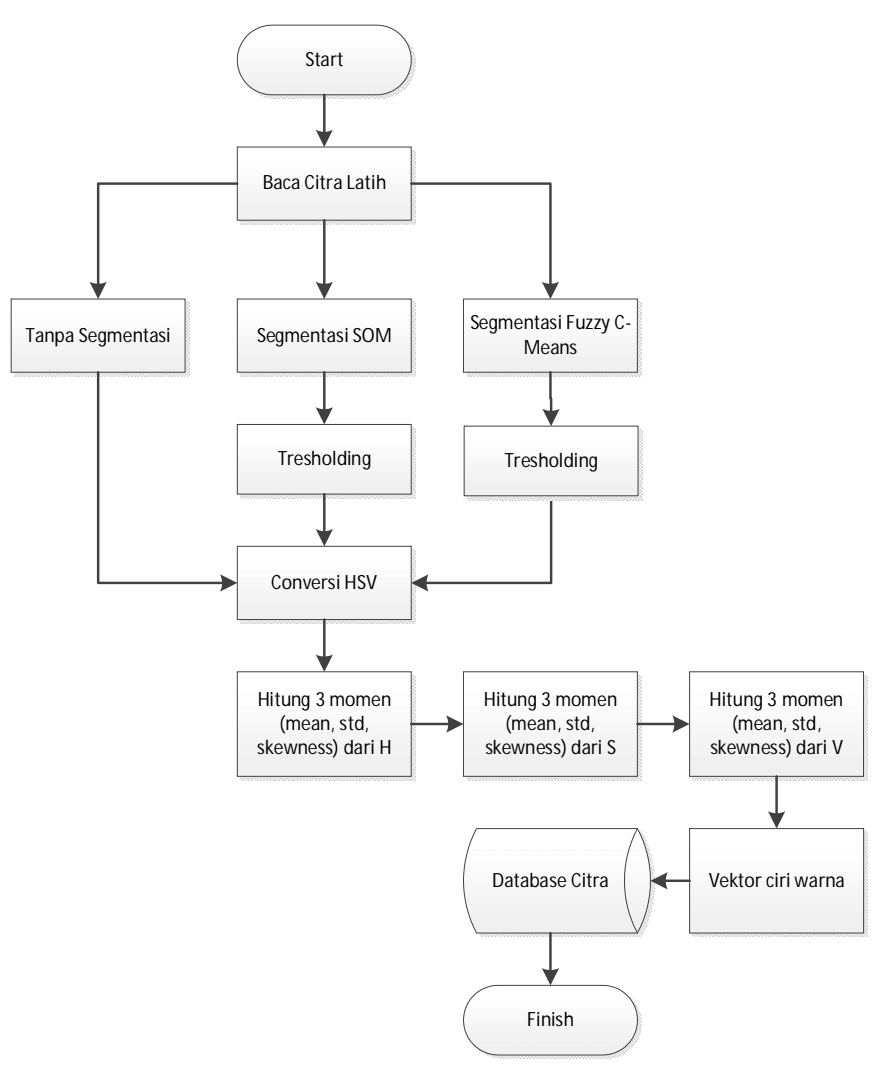

Gambar 1: Alur pelatihan citra.

Pada proses citra latih, citra mengalami tiga proses yang berbeda yaitu: segmentasi dengan Metode SOM, segmentasi dengan Metode Fuzzy C-Means dan tanpa segmentasi. Adapun output dari masing-masing segmentasi adalah segmen citra yang terbagi dalam dua segmen citra yang berbeda. Setelah itu citra dikonversi kedalam ruang warna HSV. Output dari proses ini adalah vektor ciri warna yang siap disimpan kedalam database. Proses pelatihan ini dikelompokkan menjadi sepuluh kelompok citra berdasarkan kelas citra latih yaitu sebanyak 100 citra pada masing-masing kelas citra.

Pengujian dilakukan pada tiga skema pengujian, yaitu Metode CBIR Color Moment dengan Metode Segmentasi SOM, Metode CBIR Color Moment dengan Metode Segmentasi Fuzzy C-Means dan Metode CBIR Color Moment tanpa melalui proses segmentasi citra. Hasil dari pengujian ini adalah perbandingan nilai presisi dan recall dari ketiga skema pengujian.

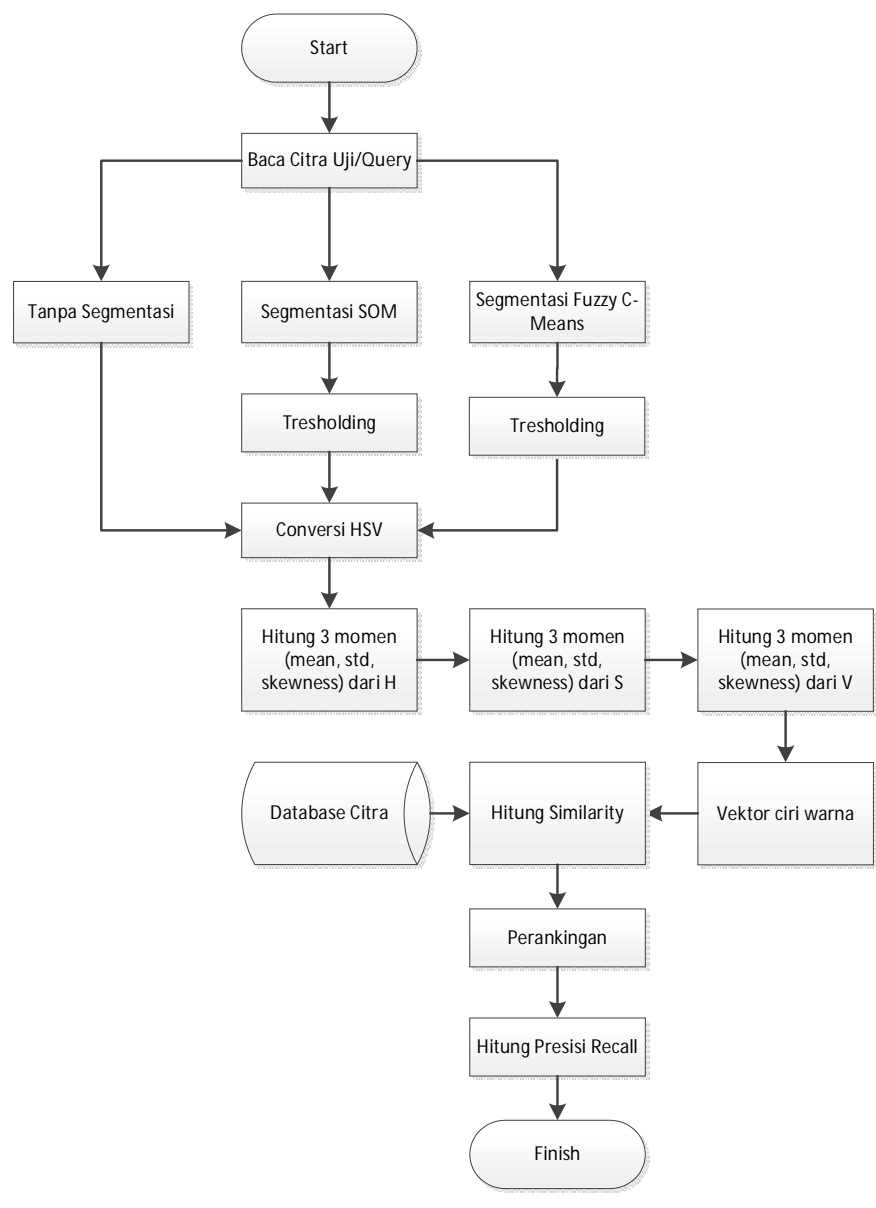

Gambar 2: Alur pengujian citra.

\section{IMPLEMENTASI SISTEM}

Implemantasi sistem menggunakan Matlab 2016, terdiri dari beberapa proses yaitu: proses pelatihan citra dan pengujian citra.

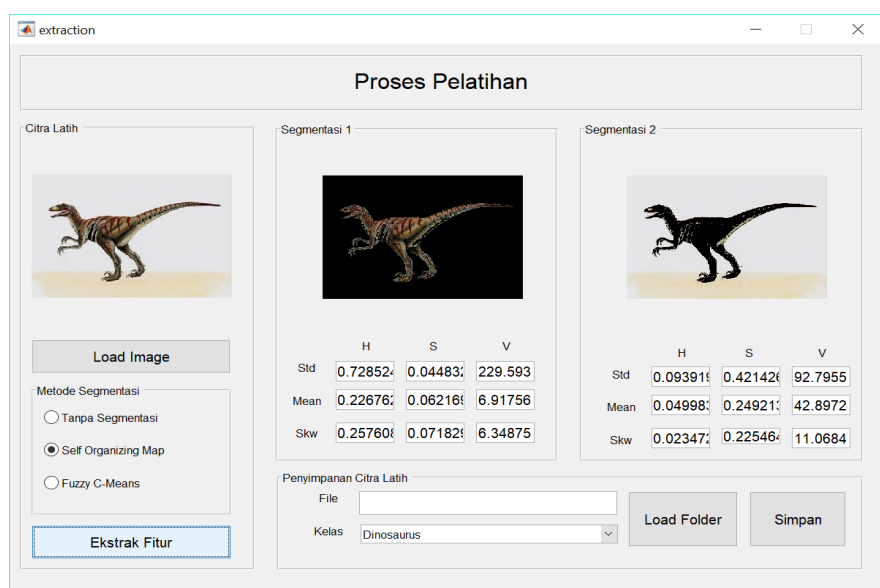

Gambar 3: Proses pelataihan citra 


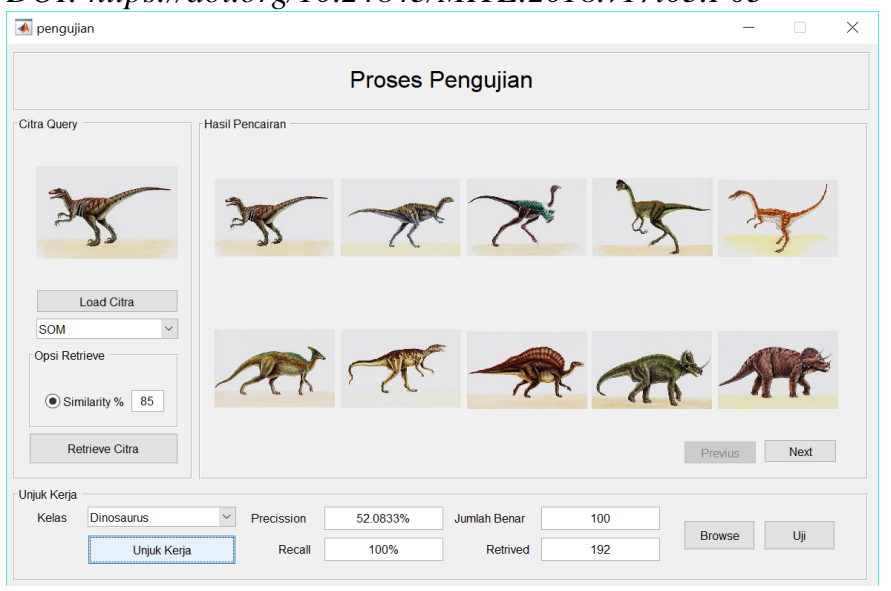

Gambar 4: Proses pengujian citra.

Proses pengujian citra dengan penurunan nilai presisi dari 100\% sampai dengan $85 \%$ pada kelas Dinosaurus didapatkan hasil pengujian dengan metode segmentasi FCM maupun SOM telah dapat menemukan kembali semua citra yang merupakan anggota kelas Dinosaurus yaitu sebanyak 100 citra dengan nilai recall maksimal sebesar $100 \%$, oleh karena itu proses pengujian selanjutnya dilakukan dengan nilai similarity $85 \%$. Citra query terdiri dari empat jenis citra yaitu citra uji tanpa mengalami perubahan, telah dilakukan preprocessing blur, memperbesar ukuran citra dan rotasi $15^{\circ}$, serta citra yang hanya mengalami pembesaran ukuran citra diambil secara acak sebanyak sepuluh citra untuk masing-masing kelas citra.

\section{HASIL DAN PEMBAHASAN}

Nilai Retrieve (Rt) menunjukkan jumlah citra yang berhasil ditemukan kembali, nilai Recall ( $\mathrm{Rc}$ ) merupakan nilai citra benar yang berhasil didapatkan, sedangkan nilai Presisi (Pr) merupakan pembagian dari nilai Recall dibagi dengan nilai Retrieve. Recall menunjukkan kuantitas citra benar yang berhasil didapat, sedangkan presisi merupakan persentase jumlah citra benar yang berhasil didapat dibandingkan dengan keseluruhan citra yang berhasil ditemukan (retrieve).

\section{A. Pengujian Citra Normal}

Berikut adalah analisis pengujian dengan menggunakan citra uji normal untuk keseluruhan kelas citra.

TABEL I

Perbandingan Citra Uji TANPA Proses Perubahan Citra

\begin{tabular}{|r|l|r|r|r|c|c|c|c|c|c|}
\hline \multirow{2}{*}{ No. } & \multirow{2}{*}{ Kelas } & \multicolumn{1}{|c|}{ Tanpa Segmentasi } & \multicolumn{3}{|c|}{ FCM } & \multicolumn{3}{|c|}{ SOM } \\
\cline { 2 - 10 } & & Rt & \multicolumn{1}{c|}{ Rc } & Pr & Rt & Rc & Pr & Rt & Rc & Pr \\
\hline 1 & 'Afrika' & 18.80 & 12.70 & 69.14 & 185.80 & 33.00 & 18.73 & 171.60 & 26.70 & 16.46 \\
\hline 2 & 'Pantai' & 3.50 & 1.30 & 64.43 & 190.40 & 28.40 & 17.02 & 188.90 & 28.90 & 18.19 \\
\hline 3 & 'Gedung' & 7.00 & 3.80 & 69.38 & 232.70 & 37.70 & 17.03 & 188.70 & 31.80 & 17.49 \\
\hline 4 & 'Bus' & 3.80 & 3.30 & 92.08 & 141.30 & 26.50 & 21.73 & 124.70 & 21.70 & 17.23 \\
\hline 5 & 'Dinosaurus' & 16.20 & 15.90 & 98.28 & 189.70 & 97.50 & 53.64 & 184.60 & 99.60 & 56.39 \\
\hline 6 & 'Gajah' & 5.90 & 4.30 & 71.83 & 236.30 & 37.30 & 15.53 & 229.90 & 33.10 & 13.93 \\
\hline 7 & 'Bunga' & 8.70 & 5.30 & 66.60 & 191.20 & 35.00 & 18.12 & 141.40 & 32.10 & 26.01 \\
\hline 8 & 'Kuda' & 11.20 & 9.80 & 86.13 & 157.10 & 30.00 & 22.54 & 145.30 & 26.20 & 18.67 \\
\hline 9 & 'Gunung' & 2.00 & 1.40 & 84.00 & 226.90 & 27.90 & 12.29 & 200.30 & 26.00 & 12.92 \\
\hline 10 & 'Makanan' & 8.30 & 6.40 & 71.89 & 177.20 & 29.40 & 16.96 & 163.00 & 31.40 & 19.56 \\
\hline \multicolumn{1}{|c|}{ Rata-Rata } & 8.54 & 6.42 & 77.38 & 192.86 & 38.27 & 21.36 & 173.84 & 35.75 & 21.68 \\
\hline
\end{tabular}

I Gusti Ngurah Winanda Wijaksana: Perbandingan Metode Segmentasi SOM... $\quad$ p-ISSN:1693 - 2951; e-ISSN: 2503-2372

Grafik Presisi Citra Uji Normal

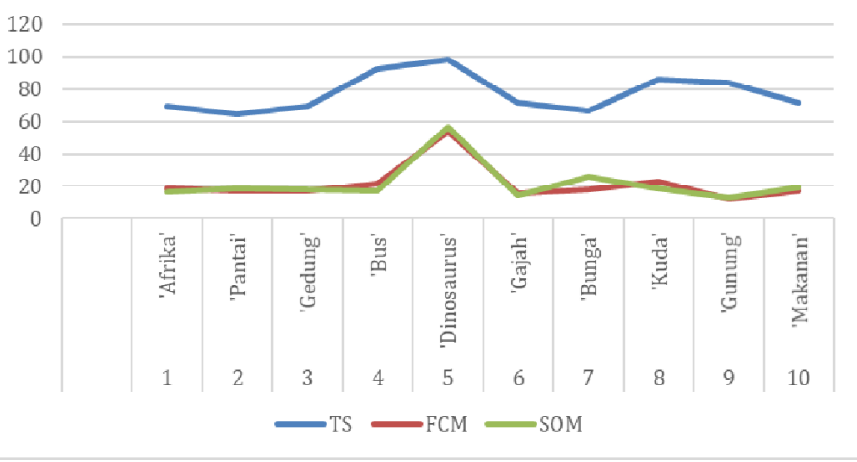

Gambar 5: Grafik nilai presisi citra uji tanpa proses perubahan citra.

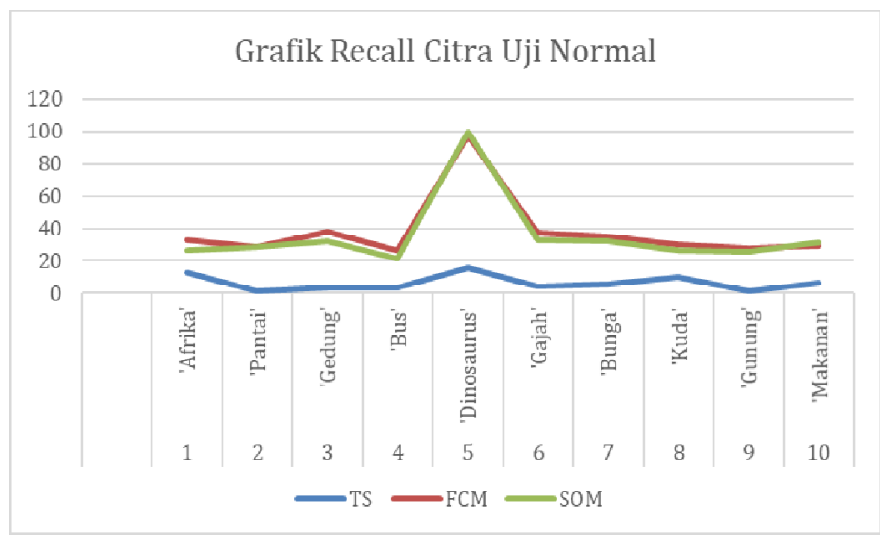

Gambar 6: Grafik nilai recall citra uji tanpa proses perubahan citra.

Gambar 5, menunjukkan nilai presisi yang dihasilkan dari citra uji yang tidak mengalami proses perubahan. Terlihat nilai presisi tertinggi ditunjukkan pada proses yang tanpa menggunakan metode segmentasi citra. Nilai presisi secara drastis turun ketika diuji pada pengujian dengan menggunakan metode segmentasi. Nilai presisi tertinggi tanpa menggunakan metode segmentasi berada pada kelas dinosaurus dengan nilai presisi $98.28 \%$ dan nilai presisi terendah berada pada kelas pantai dengan nilai presisi $64.43 \%$. Secara keseluruhan ratarata nilai presisi tanpa menggunakan metode segmentasi sebesar $77.38 \%$. Nilai presisi tertinggi pada metode segmentasi FCM berada pada kelas dinosaurus dengan nilai presisi hanya mencapai $53.64 \%$, sedangkan rata-rata nilai presisi dengan metode FCM hanya mencapai $21.36 \%$. Hasil presisi yang rendah juga didapat pada pengujian dengan menggunakan metode segmentasi SOM, nilai presisi tertinggi berada pada kelas dinosaurus yang hanya mencapai $56.39 \%$ sedangkan rata-rata presisi hanya sebesar $21.68 \%$. nilai presisi yang cukup rendah dengan menggunakan segmentasi menunjukkan proses segmentasi citra tidak mampu menghasilkan nilai presisi yang lebih baik dibandingkan dengan tidak menggunakan metode segmentasi sama sekali.

Hal sebaliknya terjadi saat pengujian nilai recall seperti ditunjukkan pada Gambar 6, nilai recall justru berbanding terbalik dengan nilai presisi. Nilai recall tertinggi dengan tanpa menggunakan metode segmentasi hanya sebesar $15.90 \%$ 
pada kelas dinosaurus. Nilai ini menunjukkan dari 100 citra benar yang terdapat pada kelas dinosaurus hanya 15 citra saja yang berhasil ditemukan kembali (retrieve). Rata-rata keseluruhan kelas hanya mencapai nilai recall sebesar $6.24 \%$. nilai recall secara signifikan naik jika menggunakan metode segmentasi. Nilai recall dengan menerapkan metode segmentasi FCM tertinggi berada pada kelas dinosaurus sebesar $97.50 \%$, nilai ini menunjukkan dari 100 citra benar, terdapat rata-rata 97.5 citra yang berhasil ditemukan kembali (retrieve). Rata-rata recall untuk keseluruhan kelas sebesar $38,27 \%$. Nilai recall dengan menggunakan metode SOM tertinggi berada pada kelas dinosaurus sebesar $99.60 \%$ dan rata-rata nilai recall untuk keseluruhan kelas sebesar $35.75 \%$.

Berdasarkan pengamatan dapat disimpulkan bahwa nilai recall naik secara signifikan dengan menggunakan metode segmentasi baik SOM maupun FCM. Nilai recall menunjukkan kuantitas citra benar yang berhasil ditemukan kembali cukup tinggi. Namun nilai presisi yang didapat berbanding terbalik dengan nilai recall yang berhasil didapat. Nilai presisi menurun drastis ketika penerapan metode segmentasi digunakan. Dapat disimpulkan bahwa penggunaan metode segmentasi berhasil meningkatkan kuantitas citra benar (recall) dan dengan tanpa menggunakan metode segmentasi dapat meningkatkan kualitas hasil pencarian (presisi).

\section{B. Pengujian Citra dengan Pembesaran}

Berikut adalah analisis pengujian dengan menggunakan citra uji dengan pembesaran untuk keseluruhan kelas citra.

TABEL II

PERBANDINGAN CitRa Uji YANG MENGaLAMI PEMBESARAN

\begin{tabular}{|c|c|c|c|c|c|c|c|c|c|c|}
\hline \multirow{2}{*}{ To. } & \multirow{2}{*}{ Kelas } & \multicolumn{3}{|c|}{ Tanpa Segmentasi } & \multicolumn{3}{|c|}{ FCM } & \multicolumn{3}{|c|}{ SOM } \\
\hline & & $\mathbf{R t}$ & Re & Pr & $\mathbf{R t}$ & $\mathbf{R c}$ & Pr & $\mathbf{R t}$ & Rc & Pr \\
\hline 1 & 'Afri & 18.20 & 12.90 & 70.04 & 182.80 & 32.10 & 19.65 & 5.80 & 1.40 & \\
\hline 2 & 'Pant & .60 & 1.20 & 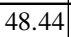 & 177.70 & 25.60 & 16.70 & 33.80 & 22.30 & \\
\hline 3 & & & 4.00 & & & 37.00 & \begin{tabular}{|l|}
17.75 \\
\end{tabular} & 30 & 33.1 & \\
\hline 4 & 'Bus' & & 20 & & & 35.20 & 25.12 & 33.00 & \begin{tabular}{|l|}
23.90 \\
\end{tabular} & 15 . \\
\hline 5 & & & & & & 20 & 51.41 & .30 & 94.50 & \begin{tabular}{|l|}
54.63 \\
\end{tabular} \\
\hline- & & & & & & 30 & 14.30 & 00 & 22. & 11.86 \\
\hline 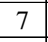 & & & & & 0 & & 16.06 & 0.60 & 33. & 18.5 \\
\hline 8 & & & & & 44. & & 18.80 & 2.20 & 26.3 & 16.2 \\
\hline 9 & & & & & 21 & & 12.78 & 11.40 & 26.6 & 13.0 \\
\hline 10 & & & 0.1 & 8.8 & 204.80 & 33.30 & 16.22 & 190.00 & 31.10 & 16.7. \\
\hline & & 7.35 & 4.92 & 60.26 & 194.23 & 37.50 & \begin{tabular}{|l|}
20.88 \\
\end{tabular} & 176.20 & 33.51 & 9.5 \\
\hline
\end{tabular}

Pengujian dengan menggunakan citra uji yang sudah diperbesar, digunakan untuk menguji kinerja metode CBIR untuk menemukan kembali citra yang sudah mengalami perubahan operasi geometri pada citra, dalam hal ini operasi perubahan skala citra. Kelas citra dinosaurus yang memiliki karakteristik citra dengan latar belakang yang solid tidak mengalami perubahan kinerja yang signifikan. Presisi tertinggi tanpa menggunakan metode segmentasi maupun menggunakan metode segmentasi masih ada pada kelas citra dinosaurus. Sedangkan pengujian recall tertinggi berada pada kelas afrika. Hal ini berbeda saat pengujian dilakukan pada citra uji normal.

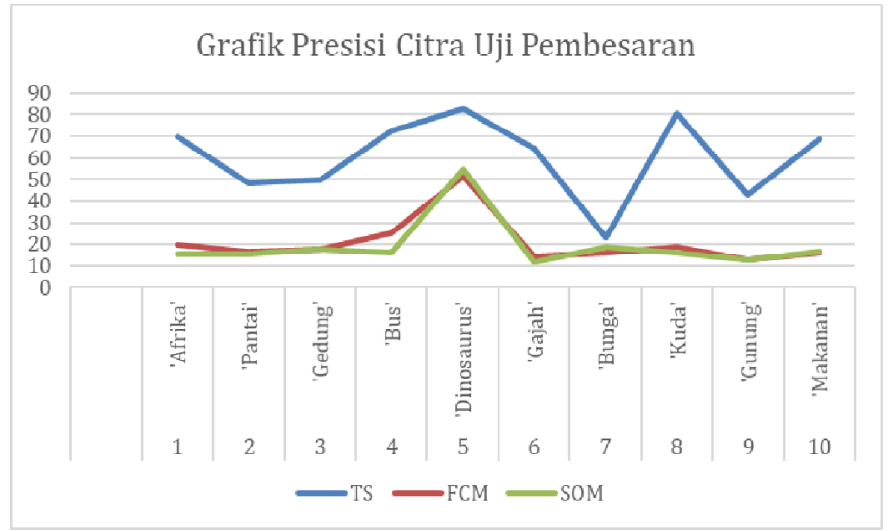

Gambar 7: Grafik nilai presisi citra uji yang mengalami pembesaran.

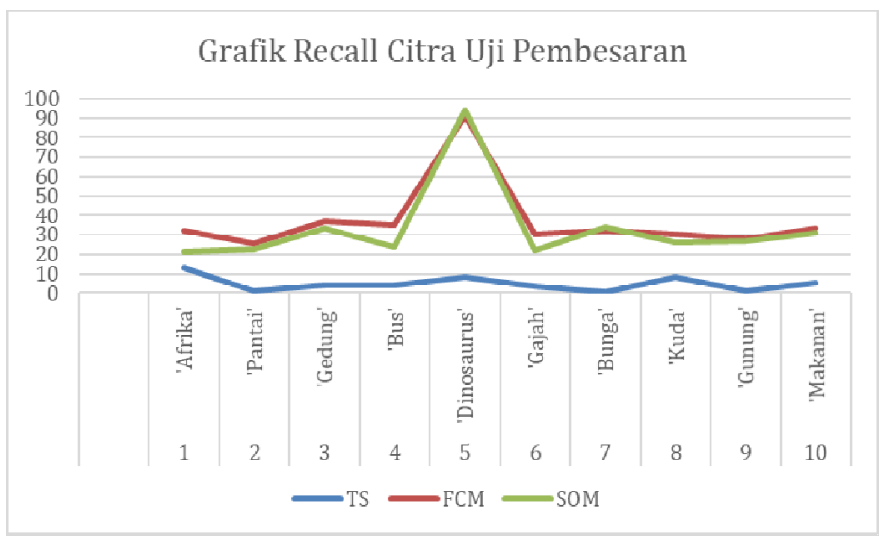

Gambar 8: Grafik nilai recall citra uji yang mengalami pembesaran.

Karakteristik citra pada kelas afrika yang dominan warna gelap menghasilkan tingkat pencarian citra benar yang lebih banyak. Jadi dapat disimpulkan bahwa perubahan operasi geometri citra dengan pembesaran skala tidak berpengaruh terhadap kinerja presisi pencarian citra.

\section{Pengujian Citra dengan Rotasi}

Berikut adalah analisis pengujian dengan menggunakan citra uji dengan mengalami rotasi untuk keseluruhan kelas citra.

TABEL III

PERBANDINGAN CITRA UJI YANG MENGALAMI RotASI

\begin{tabular}{|r|l|r|r|c|c|c|c|c|c|c|}
\hline \multirow{2}{*}{ No. } & \multirow{2}{*}{ Kelas } & \multicolumn{1}{|c|}{ Tanpa Segmentasi } & \multicolumn{3}{|c|}{ FCM } & \multicolumn{3}{|c|}{ SOM } \\
\cline { 3 - 10 } & & Rt & Rc & Pr & Rt & Rc & Pr & Rt & Rc & Pr \\
\hline 1 & 'Afrika' & 15.40 & 11.20 & 73.67 & 178.40 & 33.30 & 20.68 & 147.70 & 23.90 & 16.87 \\
\hline 2 & 'Pantai' & 4.90 & 1.20 & 34.84 & 148.90 & 20.60 & 16.74 & 155.20 & 21.90 & 15.72 \\
\hline 3 & 'Gedung' & 10.60 & 3.40 & 41.00 & 213.10 & 36.40 & 17.85 & 174.80 & 30.00 & 18.13 \\
\hline 4 & 'Bus' & 4.60 & 3.20 & 57.87 & 141.60 & 31.50 & 25.07 & 138.80 & 24.50 & 17.59 \\
\hline 5 & 'Dinosaurus' & 6.90 & 6.50 & 77.47 & 182.20 & 88.00 & 50.69 & 171.40 & 85.10 & 50.80 \\
\hline 6 & 'Gajah' & 7.00 & 3.40 & 34.62 & 202.80 & 28.50 & 14.29 & 173.00 & 18.80 & 9.42 \\
\hline 7 & 'Bunga' & 1.40 & 0.40 & 24.00 & 181.60 & 27.10 & 14.92 & 231.70 & 34.60 & 16.12 \\
\hline 8 & 'Kuda' & 9.20 & 7.50 & 79.63 & 192.50 & 28.80 & 16.95 & 157.80 & 23.70 & 15.97 \\
\hline 9 & 'Gunung' & 1.90 & 0.90 & 37.62 & 208.10 & 27.30 & 12.88 & 199.80 & 24.90 & 12.30 \\
\hline 10 & 'Makanan' & 6.80 & 5.30 & 57.00 & 200.80 & 31.40 & 15.90 & 182.80 & 30.00 & 16.22 \\
\hline \multicolumn{2}{|c|}{ Rata-Rata } & 6.87 & 4.30 & 51.77 & 185.00 & 35.29 & 20.60 & 173.30 & 31.74 & 18.91 \\
\hline
\end{tabular}




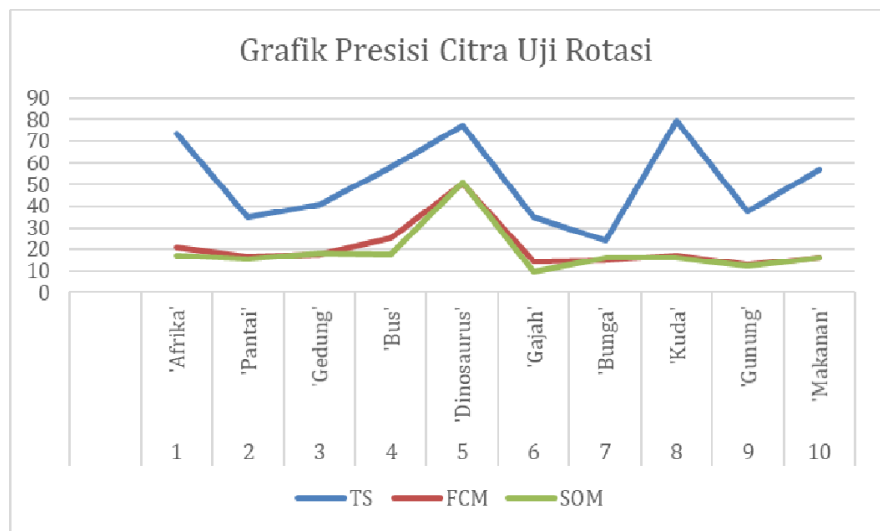

Gambar 9: Grafik nilai presisi citra uji yang mengalami rotasi.

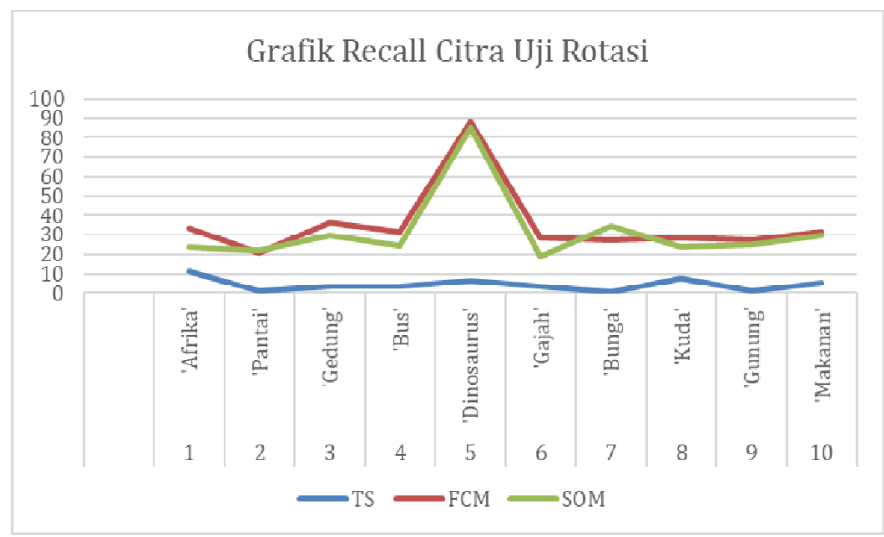

Gambar 10: Grafik nilai recall citra uji yang mengalami rotasi.

Pengujian dengan menggunakan citra uji yang telah dirotasi bertujuan untuk menguji pengaruh operasi geometri pada citra dengan perubahan skala citra dan derajat kemiringan citra. Pada pengujian dengan menggunakan citra uji rotasi mengalami dua kali proses yaitu proses pembesaran citra dan proses rotasi citra sebesar $15^{\circ}$. Kelas citra yang memiliki nilai presisi tertinggi masih pada kelas citra dinosaurus. Perubahan yang sama terjadi pada kelas citra dengan nilai rata-rata recall tertinggi. Nilai recall tertinggi berada pada kelas citra afrika, sama seperti pengujian dengan menggunakan citra uji pembesaran. Jadi dapat disimpulkan nilai presisi dan recall tertinggi dengan menggunakan metode segmentasi berada pada kelas dinosaurus. Sedangkan pada pengujian tanpa metode segmentasi, kelas citra dinosaurus memiliki nilai presisi teringgi dan kelas citra afrika memiliki nilai recall tertinggi.

\section{Pengujian Citra dengan Pengaburan}

Pengujian dengan menggunakan citra uji pengaburan, bertujuan untuk mengetahui kinerja metode CBIR untuk menemukan kembali citra yang sudah mengalami perubahan spasial. Proses pengaburan citra, mengurangi detail citra menjadi lebih sederhana. Berikut adalah analisis pengujian dengan menggunakan citra uji dengan mengalami pengaburan untuk keseluruhan kelas citra.
TABEL IV

Perbandingan Citra Uji Yang Mengalami Pengaburan

\begin{tabular}{|c|c|c|c|c|c|c|c|c|c|c|}
\hline \multirow[b]{2}{*}{ No. } & \multirow[b]{2}{*}{ Kelas } & \multicolumn{3}{|c|}{ Tanpa Segmentasi } & \multicolumn{3}{|c|}{ FCM } & \multicolumn{3}{|c|}{ SOM } \\
\hline & & $\mathbf{R t}$ & Rc & $\mathbf{P r}$ & Rt & Rc & Pr & $\mathbf{R t}$ & Rc & Pr \\
\hline 1 & 'Afrika' & 10.10 & 6.70 & 71.44 & 1 & 26.40 & 13.26 & 30 & 21.60 & \\
\hline 2 & 'Pant & 40 & 1.50 & 71.67 & 152.20 & 24.60 & 25.12 & 167.00 & 2 & \\
\hline 3 & 'Gec & 90 & 1.00 & 23.10 & 168.50 & 24.80 & 15.16 & 9.40 & 23.10 & 14.6 \\
\hline 4 & 'Bus & 1.70 & 0.80 & 52.50 & 145.30 & 15.30 & 11.35 & 135.10 & 14.80 & 13.0 \\
\hline 5 & 'Din & 12.80 & 12.00 & 9 & 172.20 & .30 & 95 & 90 & 0 & 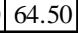 \\
\hline 6 & 'G & & 70 & 0 & 20 & 0 & 1 & 10 & 34.50 & 1 \\
\hline 7 & 'B & & 10 & .36 & & & 0.01 & & 31 & 30 \\
\hline 8 & & & & 98. & & 2 & 24.78 & 50 & 19.90 & 18.7 \\
\hline 9 & & & 1. & 76. & & & 12.37 & 36.70 & 17.00 & 12.1 \\
\hline 10 & & & 3.8 & 71 & 173 & 25. & 15.01 & 142.40 & 21.80 & 14.7 \\
\hline & Na-Nata & 4.8 & 04 & 10 & 166.69 & 32.52 & 21.68 & 156.62 & 30.54 & 22.0 \\
\hline
\end{tabular}

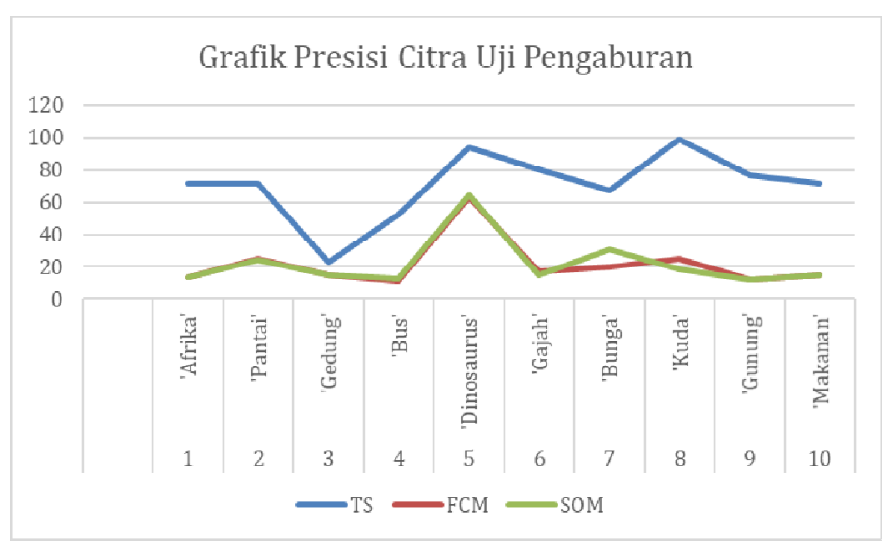

Gambar 11: Grafik nilai presisi citra uji yang mengalami pengaburan.

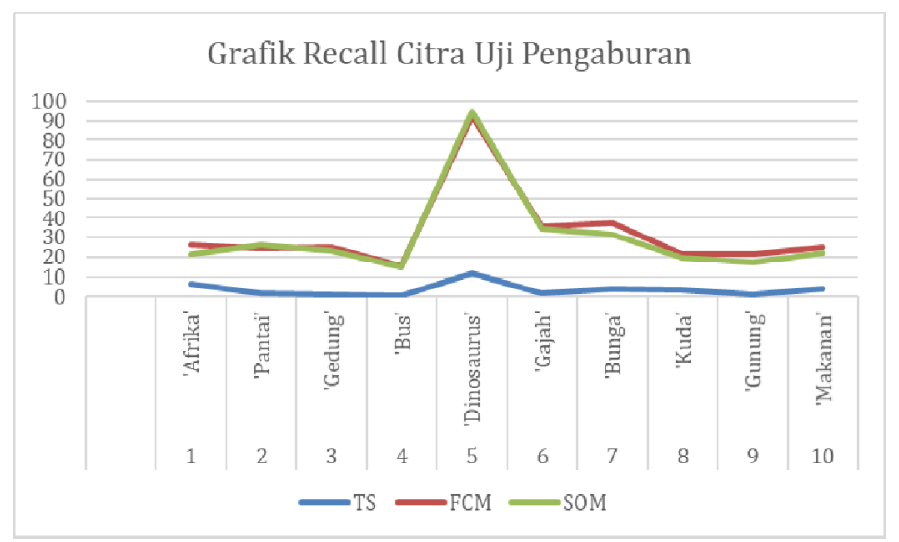

Gambar 12: Grafik nilai recall citra uji yang mengalami pengaburan.

Hasil pengujian menunjukkan kesamaan pola nilai presisi dan recall tertinggi pada kelas citra dinosaurus dengan menggunakan metode segmentasi SOM maupun FCM. Sedangkan pengujian tanpa menggunakan metode segmentasi menunjukkan nilai presisi tertinggi masih ada pada kelas citra dinosaurus dan nilai recall tertinggi terdapat pada kelas citra kuda. Hal ini menunjukkan karakteristik kelas citra kuda menunjukkan hasil recall yang lebih baik ketika diuji dengan citra dengan tingkat detail citra uji yang sudah dikurangi.

Secara umum berdasarkan seluruh pengujian yang telah dilakukan dapat digambarkan sebagai berikut: (1) Nilai ratarata presisi tertinggi didapat pada pengujian dengan tanpa 
menggunakan metode segmentasi pada seluruh jenis citra uji. (2) Nilai rata-rata presisi lebih tinggi didapat dengan menggunakan metode segmentasi SOM dibandingkan dengan metode segmentasi FCM pada pengujian citra uji normal dan citra yang sudah mengalami perubahan spasial citra dengan pengaburan. Sedangkan pada pengujian citra yang sudah mengalami perubahan operasi geometri pada citra dengan perubahan skala/pembesaran dan rotasi, nilai presisi lebih tinggi didapat dari metode segmentasi FCM. Hal ini membuktikan bahwa metode SOM lebih toleran terhadap perubahan spasial citra, sedangkan metode FCM lebih toleran terhadap perubahan operasi geometri pada citra. (3) Nilai recall tertinggi didapat dengan menggunakan metode segmentasi FCM untuk keseluruhan jenis citra uji, hanya terpaut rata-rata $3.01 \%$ dibandingkan dengan metode SOM pada seluruh jenis citra uji. (4) Pengujian dengan menggunakan pembesaran, rotasi dan pengaburan tidak berpengaruh terhadap nilai presisi tertinggi untuk masingmasing jenis pengujian. Perubahan nilai recall tertinggi hanya terjadi pada pengujian dengan tanpa menggunakan metode segmentasi. (5) Nilai rata-rata presisi dan recall tertinggi di semua jenis pengujian berada pada kelas Dinosaurus karena secara pengamatan citra, kelas dinosaurus merupakan citra yang memiliki background dengan warna yang solid sehingga keberhasilan metode segmentasi dalam memisahkan antara foreground dengan background lebih baik dibandingkan kelaskelas citra yang memiliki background yang serupa dengan foregroundnya.

\section{KESIMPULAN}

Berdasarkan hasil pengujian yang telah dilakukan dapat disimpulkan beberapa hal sebagai berikut:

1. Metode segmentasi SOM menghasilkan nilai presisi yang lebih tinggi daripada metode FCM pada pengujian citra uji normal dan citra dengan pengaburan. Sedangkan pada pengujian citra yang sudah mengalami perubahan skala/pembesaran dan rotasi, nilai presisi lebih tinggi dihasilkan dengan menggunakan metode segmetasi FCM serta nilai recall yang lebih tinggi di semua jenis pengujian.

2. Penambahan metode segmentasi SOM dan FCM sebelum proses pencarian citra, meningkatkan nilai recall atau nilai jumlah citra benar yang berhasil ditemukan, sedangkan nilai presisi menurun dibandingkan dengan tanpa menggunakan metode segmentasi.

\section{REFERENSI}

[1] R. Yuniarti, H. Tjandrasa, A. Yuniarti, "Implementasi Sistem Temu Kembali Citra Berbasis Isi Dengan Metode Jarak Informasi Yang Dinormalisasi”, Makalah Seminar Tugas Akhir, Periode Juni-Juli 2010.

[2] S. Mangijao, K. Hemachandran, "Content-Based Image Retrieval using Color Moment and Gabor Texture Feature." Department of Computer Science, Assam University, Silchar, Assam, India, 2012.

[3] D. C. Khrisne, M. D. Yusanto, "Content-Based Image Retrieval Menggunakan Metode Block Truncation Algorithm dan Grid Partitioning", Jurnal Ilmu Komputer dan Sains Terapan, vol. 5, n. 2, April 2014

[4] “J. Z. Wang Dataset”, Penn State, University Park, Pennsylvania.

[5] A. A. G. B. Ariana, I K. G. D. Putra, Linawati, "Perbandingan Metode SOM/Kohonen dengan ART 2 pada Data Mining Perusahaan Retail", Majalah Ilmiah Teknologi Elektro, vol. 16, n. 2, p. 55-59, Agustus 2017.

[6] A. K. Muchsin, M. Sudarma. "Penerapan Fuzzy C-Means untuk Menentukan Besar Uang Kuliah Tunggal Mahasiswa Baru”. Lontar Komputer, vol. 6, n. 3, Desember 2015.

[7] I M. B. Adnyana, I K. G. D. Putra, I P. A. Bayupati, "Segmentasi Citra Berbasis Clustering Menggunakan Algoritma Fuzzy C-Means", Majalah Ilmiah Teknologi Elektro, vol. 14, n. 1, Juni 2015.

[8] I K. Ariana, R. S. Hartati, I K. G. D. Putra, N. K. A. Wirdiani, "Color Image Segmentasi using Kohonen Self-Organizing Map (SOM)". International Journal of Engineering and Technology (IJET), vol. 6, n. 2, April-Mei 2014. 